\title{
EFFECT OF ELASTIC-BAND EXERCISE ON MUSCLE DAMAGE AND INFLAMMATORY RESPONSES IN TAEKWONDO ATHLETES
}

\author{
EFEITO DO EXERCÍCIO COM BANDA ELÁSTICA SOBRE A LESÃO MUSCULAR E AS RESPOSTAS \\ INFLAMATÓRIAS EM ATLETAS DE TAEKWONDO
}

\author{
EFECTOS DE LOS EJERCICIOS CON BANDA ELÁSTICA SOBRE LA LESIÓN MUSCULAR \\ $Y$ LAS RESPUESTAS INFLAMATORIAS EN ATLETAS DE TAEKWONDO
}

\author{
Keivan Gadruni ${ }^{1}$ \\ (Physical Educator) \\ Hemn Mohammadpour ${ }^{2}$ \\ (Veterinarian) \\ Mohammad Gadruni ${ }^{1}$ \\ (Physical Educator) \\ 1. University of Tabriz, Faculty \\ of Education and Psychology, \\ Department of Physical Education \& \\ Sport Science, IR, Iran. \\ 2. Tarbiat Modares University, \\ Faculty of Medical Science, \\ Department of Medical \\ Immunology, Tehran, Iran.

\section{Correspondence:} \\ Hemn Mohammadpour, \\ University of Tabriz, Faculty of \\ Veterinary Medicine Iran, East \\ Azerbayjan, Abresan square, 29th \\ bahman Blv. Iran. \\ h.mohammadpour@modares.ac.ir
}

\begin{abstract}
Introduction: Elastic bands offer variable elastic resistance (ER) throughout a range of motion and their incorporation with exercise movements has been used for variable strength training and rehabilitation purposes. Objective: Investigate the effect of acute bout of progressive elastic-band exercise on muscle damage and inflammatory response in Taekwondo athletes (TKD) compared with untrained ones. Methods: Fourteen ( $T K D, n=7$ and untrained, $n=7$ ) men performed 3 sets of progressive resistance elastic exercise. Blood samples were taken pre-exercise and also immediately and $24 \mathrm{~h}$ post exercise. Delayed onset muscle soreness (DOMS), creatine kinase (CK) and lactate dehydrogenase (LDH) activity, total leukocyte counts, interleukin-6 and C-reactive protein (CRP) were analyzed. Results: Only DOMS increased in untrained group, but elevation of DOMS was observed in both groups (TKD and untrained) at 24h after exercise ( $p<0.05)$. CK and LDH activity increased in both groups significantly. Also TKD group only showed CK increasing 24h post exercise $(p<0.05)$. Total circulating leukocyte counts increased immediately in post exercise experiments and decreased in $24 \mathrm{~h}$ ones in both groups $(p<0.05)$. Serum IL-6 immediately increased in both groups and $24 \mathrm{~h}$ post exercises but there was no significant difference between immediate and 24h post exercise experiments in TKD group. Furthermore, CRP just increased 24h after exercise in both groups ( $p<0.05)$. Conclusion: Progressive resistance elastic exercise induced muscle damage and inflammation in TKD athletes, but also had smaller changes in comparison with untrained group and other forms of exercise.
\end{abstract}

Keywords: resistance training, sports, biological markers, inflammation, acute-phase reaction.

\section{RESUMO}

Introdução: As bandas elásticas oferecem resistência elástica (RE) variável em toda a amplitude de movimento, e sua incorporação aos movimentos de exercício tem sido utilizada para fins variáveis de treinamento de força e de reabilitação. Objetivo: Investigar o efeito de ciclos agudos de exercício progressivo com banda elástica sobre os danos e respostas inflamatórias dos músculos em atletas de Taekwondo (TKD), em comparação com os indivíduos não treinados. Métodos: Catorze (TKD, $n=7$ e não treinados, $n=7$ ) homens realizaram três conjuntos de exercício elástico com resistência progressiva. Foram coletadas amostras de sangue antes, imediatamente após e 24 horas depois do exercício. Procederam-se às seguintes análises: dor muscular de início tardio (DMIT), atividade da creatina quinase (CK) e da lactato desidrogenase $(\mathrm{LDH})$, contagem total de leucócitos, interleucina-6 e proteína C reativa (CRP). Resultados: Só a DMIT aumentou no grupo não treinado, mas a elevação desse parâmetro foi constatada em ambos os grupos (TKD e não treinados) 24 horas depois do exercício $(p<0,05)$. A atividade da CK e da LDH aumentou significantemente nos dois grupos. Além disso, o grupo TKD só apresentou elevação da CK 24 horas depois do exercício $(p<0,05)$. As contagens totais de leucócitos circulantes aumentaram imediatamente nas experiências pós-exercício e caíram nas experiências às 24 horas em ambos os grupos $(p<0,05)$. A IL-6 sérica aumentou de imediato nos dois grupos e 24 horas depois dos exercícios, mas não se constatou diferença significante entre as experiências imediatas e depois de 24 horas no grupo TKD. Além disso, a CRP aumentou apenas 24 horas após o exercício nos dois grupos $(p<0.05)$. Conclusão: O exercício progressivo com banda elástica induziu danos musculares e inflamação nos atletas de TKD, tendo porém, alterações menores em comparação com o grupo não treinado e com outras formas de exercício.

Palavras-chave: treinamento de resistência, esportes, marcadores biológicos, inflamação, reação de fase aguda.

\section{RESUMEN}

Introducción: Las bandas elásticas ofrecen resistencia elástica (RE) variable en toda la amplitud de movimiento, y su incorporación a los movimientos de ejercicios ha sido utilizada para fines variables de entrenamiento de fuerza y de rehabilitación. Objetivo: La finalidad del presente estudio fue investigar el efecto de ciclos agudos de ejercicios progresivos con banda elástica sobre los daños y respuestas inflamatorias de los músculos en atletas de Taekwon- 
do (TKD), en comparación con los individuos no entrenados. Métodos: Catorce (TKD, $n=7$ y no entrenados, $n=7$ ) hombres realizaron tres conjuntos de ejercicios elásticos con resistencia progresiva. Fueron colectadas muestras de sangre antes, inmediatamente después y 24 horas después de los ejercicios. Se procedió a realizar los siguientes análisis: dolor muscular de inicio tardío (DMIT), actividad de creatincinasa (CK) y de lactato deshidrogenasa (LDH), conteo total de leucocitos, interleucina-6 y proteína C reactiva (CRP). Resultados: Sólo la DMIT aumentó en el grupo no entrenado, pero la elevación de ese parámetro fue constatada en ambos grupos (TKD y no entrenados) 24 horas después de los ejercicios $(p<0,05)$. La actividad de la CKy de la LDH aumentó significantemente en los dos grupos. Además, el grupo TKD sólo presentó elevación de la CK 24 horas después de los ejercicios $(p<0,05)$. Los conteos totales de leucocitos circulantes aumentaron inmediatamente en los experimentos post-ejercicio y cayeron en los experimentos a las 24 horas en ambos grupos $(p<0,05)$. La IL-6 sérica aumentó de inmediato en los dos grupos y 24 horas después de los ejercicios, pero no se constató diferencia significativa entre los experimentos inmediatos y después de 24 horas en el grupo TKD. Además de eso, la CRP aumentó solamente 24 horas después de los ejercicios en los dos grupos $(p<0.05)$. Conclusión: Los ejercicios progresivos con banda elástica indujeron daños musculares e inflamación en los atletas de TKD habiendo, no obstante, alteraciones menores en comparación con el grupo no entrenado y con otras formas de ejercicio.

Palabras clave: entrenamiento de resistencia, deportes, marcadores biológicos, inflamación, reacción de fase aguda.

\section{INTRODUCTION}

During Taekwondo matches, the strikes which are delivered correctly to the opponent may bring about points when they are managed above a certain level of strength. In order to get points during Taekwondo matches, one should be able to display a high level of neuromuscular coordination to stop the opponent, or to deliver strikes with great force to shock and imbalance the opponent. Training sessions conducted with elastic bands have replaced the traditional training methods where free weight formed the backbone of the training?.

Elastic bands offer variable elastic resistance (ER) and nautilus machine (NM) throughout a range of motion and their incorporation with exercise movements has been used for variable strength training and rehabilitation purposes. Additionally elastic exercise has been used in strength training as a means to create an over-speed eccentric phase, which has been shown to enhance the effects of the strength-shorting cycle (SCC)2.

NM and ER have gained considerable popularity among athletes and recreational lifters seeking to increase muscle strength ${ }^{3}$. This is due in part to the fact that Variable External Resistance Training (VRT) devices provide varying external resistance based on the muscle force generating capacity throughout the range of motion ${ }^{4}$. The ER exercise device is comprised of elastic band material that requires muscle force to transiently extend the length of the elastic band. Despite the popularity of ER, there is controversy concerning the use of this mode of exercise for increasing muscle hypertrophy and strength among healthy-trained individuals. This stems from an unfounded assumption that an "elastic device provides a low level of external force" and therefore is limited in providing an appropriate resistance/stimulus for strength development ${ }^{5}$.

Activity such as muscle overload and muscle stretch, or combination of both that occurs in eccentric part of elastic exercise has been shown to result in muscle damage ${ }^{6}$. Exercise-induced muscle damage has been associated with disruption of the normal myofilamentm structures in sarcomeres ${ }^{7}$, damage to sarcolemma, loss of fiber integrity and leakage of muscle-specific enzymes and proteins into the blood, acute inflammatory response ${ }^{8}$, delayed-onset muscle soreness and loss of muscle contraction force ${ }^{9}$.

Muscle adaptation that occurs following damage has been explained by the classic damage-inflammation- regeneration process. Coordination between inflammation and regeneration is crucial for successful recovery of damaged muscle ${ }^{10}$. Also, much of the acute inflammatory response induced by muscle damage is coordinated by the de novo synthesis of endogenous cytokines that direct inflammatory-related events. Cytokines may be produced by a variety of cells including endothelial cells, tissue-resident leukocytes and circulating leukocytes ${ }^{11}$. They contribute to specific aspects of acute inflammation and may be characterized as either pro- or anti-inflammatory, based on their predominant action?.

Eccentric muscle actions induce a substantial increase in serum creatine kinase (CK) activity and significant muscle soreness in the muscle groups involved. In other hand lengthening or eccentric contractions have been documented to induce skeletal muscle trauma in both human and animal models ${ }^{12}$. Therefore the inflammatory response to induced trauma could account for the progressive release of muscle-specific enzymes into the serum and feelings of soreness that are often observed in untrained subjects in the days after eccentric exercise ${ }^{13}$.

A growing number of studies are focusing on the effects of routine exercise on common hematological and biochemical blood marker of muscle damage and inflammation, in an attempt to provide improved insight into the choices best exercise to athletes and reduce the muscle damage.

To author's knowledge there was no documented study about the effects of elastic band exercise on alteration of common blood markers in Taekwondo athletics. So, the aim of this study was to examine the effects of elastic band exercise on delayed onset muscle soreness (DOMS), creatine kinase (CK) and lactate dehydrogenase (LDH) activity, total leukocyte counts, interleukin-6 and C-reactive protein (CRP), as the hematological and biochemical markers on muscle damage and inflammation in Taekwondo athletes (TKD) and untrained men.

\section{METHODS}

\section{Participants}

Fourteen volunteers including of young Taekwondo athletes $(n=7)$ and untrained ( $n=7$ ) men was selected for this study. Descriptive characteristics of the participants were documented which are presented in table 1. Participants were non-smokers; they had not performed this type of exercise at least six months before the study although Taekwondo group were regularly trained (four training sessions per week), and in untrained group, participants had not regular training history. Participants were not taking any dietary supplements or anti-inflammatory drug for 
Table 1. Physical characteristics of the participants.

\begin{tabular}{c|c|c|c}
\hline Variable & $\begin{array}{c}\text { Untrained } \\
(\mathbf{N}=\mathbf{7})\end{array}$ & $\begin{array}{c}\text { TKD } \\
(\mathbf{N}=\mathbf{7})\end{array}$ & $\begin{array}{c}\text { Total } \\
(\mathbf{N}=\mathbf{1 4})\end{array}$ \\
\hline Age (year) & $22.86 \pm 1.34$ & $22.43 \pm 1.71$ & $22.64 \pm 1.49$ \\
\hline Height $(\mathrm{cm})$ & $175.86 \pm 2.54$ & $181.43 \pm 3.45$ & $178.64 \pm 4.10$ \\
\hline Mass $(\mathrm{kg})$ & $76.86 \pm 1.77$ & $66.14 \pm 2.61$ & $71.50 \pm 5.95$ \\
\hline $\mathrm{BMl}\left(\mathrm{kg} / \mathrm{m}^{2}\right)$ & $24.85 \pm 0.81$ & $20.13 \pm 1.09$ & $22.49 \pm 2.61$ \\
\hline $\mathrm{VO}_{2 \text { max }}\left(\mathrm{ml} \mathrm{kg-}^{-1} \mathrm{~min}^{-1}\right)$ & $28.14 \pm 2.03$ & $42.14 \pm 2.19$ & $35.14 \pm 7.54$ \\
\hline
\end{tabular}

Values are mean $\pm \mathrm{SE}$.

six months before the study. In addition, all participants were informed about the nature of the aim of study, related risks and benefits, and signed an informed consent form. The study was conducted according to ethical principles, including the World Medical Association Declaration of Helsinki (version, 2002). Ethical approval was obtained from The Tabriz ethics committee of the Faculty of Medicine, Tabriz University of Medicine science, Iran.

\section{Experimental design}

Before accomplishing the exercise, subjects performed a warm up consisting of 5 minute of low-intensity running and stretching. Progressive elastic-band exercise consisted of 3 sets of hip flexion, hip extension and hip abduction exercise by elastic-band. The first length of band (cord) was un-stretch $(2.20 \mathrm{~m})$ in first set but in other sets decrease by $10 \mathrm{~cm}$ in each set. Each set of exercise consisting of performing by right and left leg. There was two resting times: three minutes between sets and five minutes between exercises (figure 1).

Perception of muscle soreness was assessed using a visual analog scale (VAS). The scale was numbered from 0 to10 that 0 indicating no muscle soreness and 10 signified that the muscles were too sore to move.

Blood samples were drawn from an antecubital vein $(10 \mathrm{ml})$ via sterile catheter for each participants, before, immediately post and $24 \mathrm{~h}$ after elastic-band exercise. Immediately after collection, $1 \mathrm{ml}$ aliquots of blood sample were analyzed for CBC-H1 (Technicon H1, Technicon, Tarrytown, NY, USA) and $9 \mathrm{ml}$ using for serum collect. Serum samples were separated from whole blood by using Vacationer blood-collection tubes by centrifugation at 1,000 $\mathrm{g}$ for $10 \mathrm{~min}$ after the blood was allowed to clot at room temperature for $30 \mathrm{~min}$. These samples were stored frozen at $-80^{\circ} \mathrm{C}$ until assayed. Serum CK and LDH activity was measured by using biochemical assay kits (Pars Azmoon, Iran) prescribed for the kinetic enzyme Alcyon 300 auto-analyzer (USA). IL-6 was determined with ELISA kits (American Bandermed) based on immunoenzymatic method. Serum CRP was measured by using commercially available solid phase high-sensitivity Enzyme-Linked Immunosorbent Assay (ALISA) kit (Pars Azmoon, Iran).

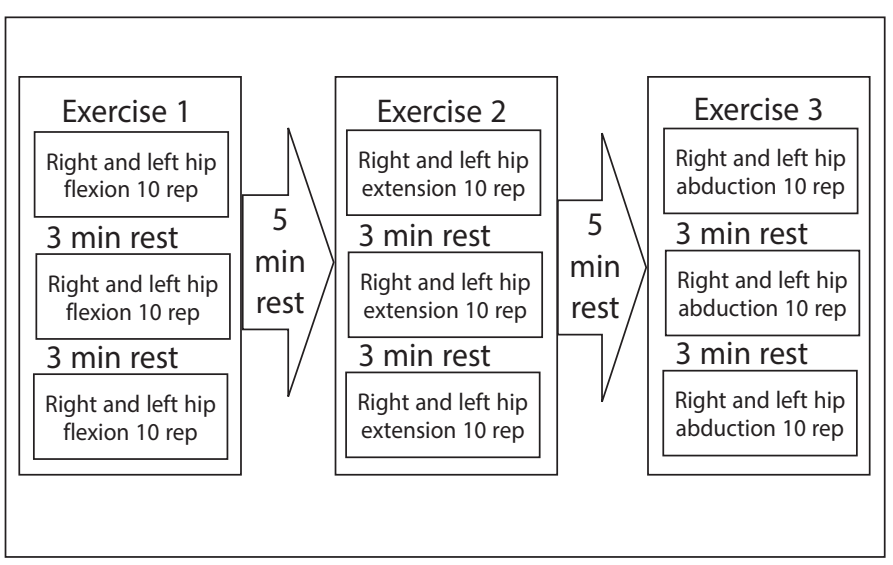

Figure 1. Exercise protocol.

\section{Statistical Analysis}

All data are presented as mean \pm SE. Validity of data was verified with the 1-sample Kolmogorov-Smirnoff test; therefore, a nonparametric test was not necessary. Data were analyzed through 2-way (group * time) repeated measures ANOVA with planned contrasts on different time points. When a significant effect was found, post hoc analysis was performed through the Bonferonni test. Significancy level was set at alpha of 0.05 .

\section{RESULTS}

Perceived muscle soreness significantly increased immediate and $24 \mathrm{~h}$ post the elastic-band exercise protocol in untrained group (from zero at the baseline to $2.86 \pm 0.9$ and $5.57 \pm 0.5$ at immediate post and $24 \mathrm{~h}$ after exercise respectively) $(\mathrm{p}<0.05)$. But in athlete group, perceived muscle soreness was not observed immediately in post exercise experiments (From zero at the baseline to $1.00 \pm 0.4$ at $24 \mathrm{~h}(\mathrm{p}<0.05)$ ). Also, perceived muscle soreness elevation in the untrained group was significantly more than the athlete group $(p<0.05)$ (figure 2$)$.

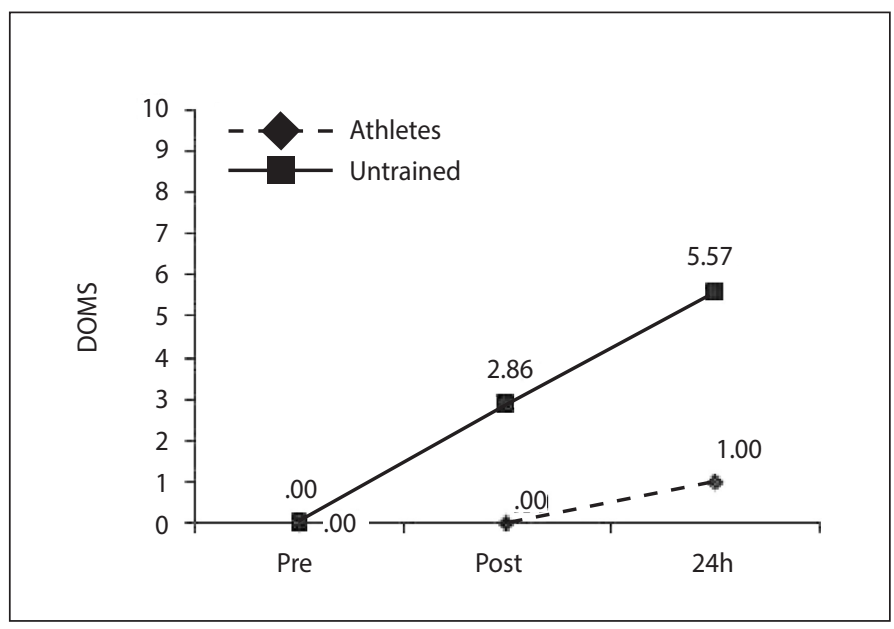

Figure 2. Baseline, changes in DOMS immediate and $24 \mathrm{~h}$ after exercise. Results expressed as mean \pm SD. $p<0.05$

\section{Serum Creatine kinase and Lactate Dehydrogenase Activity}

CK activity significantly increased following the elastic-band exercise in untrained group (87.28 $\pm 4.15 \mathrm{IU} . \mathrm{L}-1$ at immediately and $135.57 \pm 4.35$ LU.L-1 at 24h) ( $p<0.05)$, but in TKD group, significant serum CK activity difference just was observed at $24 \mathrm{~h}$ after exercise (from $72.14 \pm 1.67$ IU.L-1 at baseline to $72.86 \pm 1.86$ IU.L-1 at immediate post exercise and to $85.57 \pm 1.61$ IU.L-1 at $24 \mathrm{~h}$ after exercise), though were less than untrained ones $(p<0.05)$ (figure 3$)$. Furthermore, LDH activity increased in immediate and $24 \mathrm{~h}$ post exercise experiments in both groups $(p<0.05)$. The untrained group (190.57 \pm 4.11$)$ had showed remarkable enhancement in comparison with TKD group (178.14 \pm 2.79$)$ at $24 \mathrm{~h}$ after exercise $(p<0.05)$ (figure 4).

\section{Inflammatory Response}

\section{Leukocyte counts, Interleukin-6 and C-reactive protein}

Total circulating leukocyte count increased immediately in post exercise experiments and decreased in $24 \mathrm{~h}$ post exercise ones in both groups ( $p<0.05$ ); but its increase in untrained group (from 5.24 \pm 0.22 at baseline to $8.93 \pm 0.09$ at immediately post) was more than TKD group(from $5.62 \pm 0.22$ at baseline to $7.94 \pm 0.05$ at immediately post) $(p<0.05)$ (figure 5). Serum interleukin-6 in untrained group significantly increased in immediate and $24 \mathrm{~h}$ post exercise experiments (from $0.66 \pm 0.01$ at baseline to $1.27 \pm 0.11$ and to $1.80 \pm 0.24$ at $24 h)(p<0.05)$. 


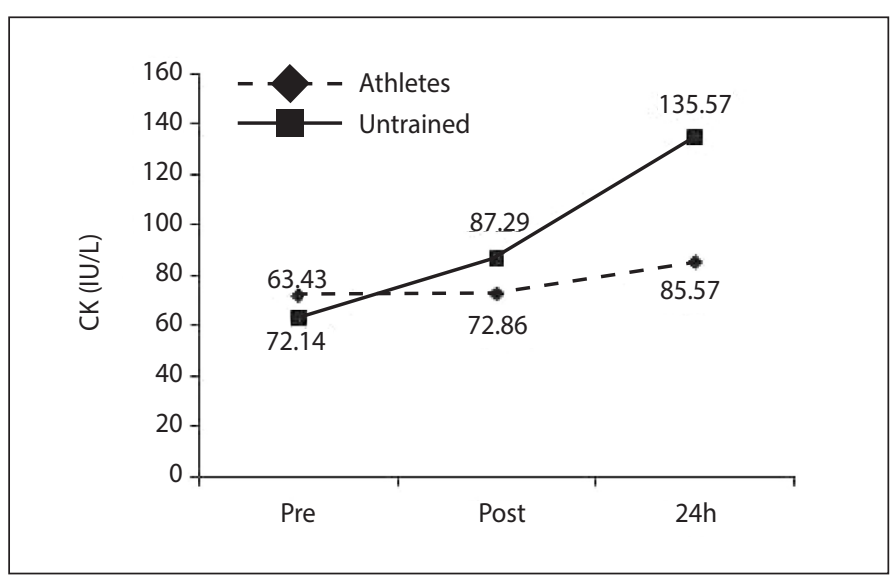

Figure 3. Baseline, changes in CK activity immediate and 24h after exercise. Results expressed as mean \pm SD. $p<0.05$

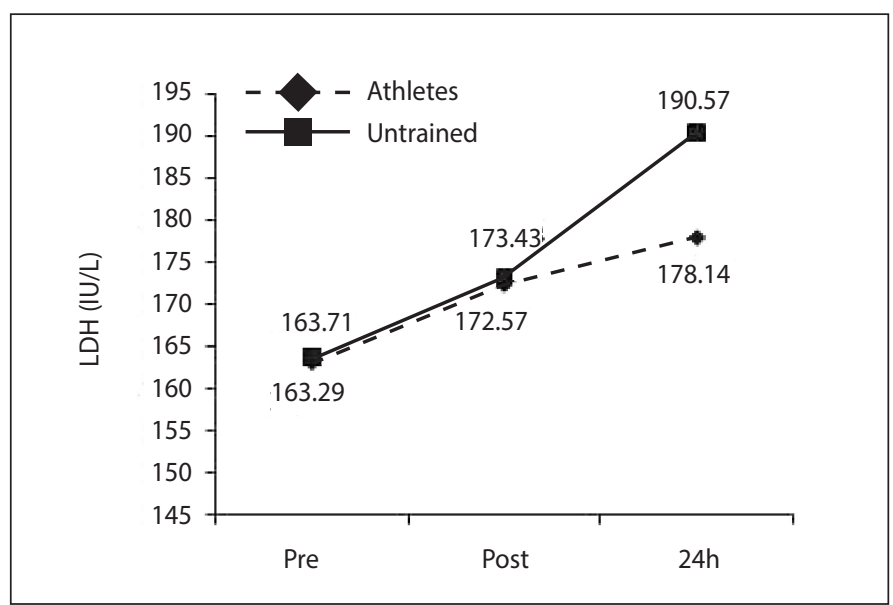

Figure 4. Baseline, changes in LDH activity immediate and $24 \mathrm{~h}$ after exercise. Results expressed as mean \pm SD. $p<0.05$.

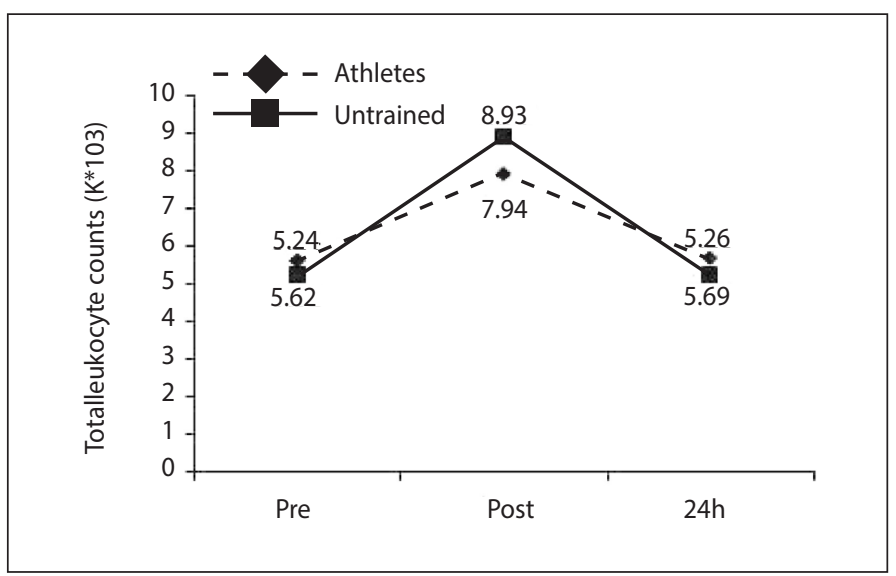

Figure 5. Baseline, changes in total leukocyte counts immediate and 24h after exercise. Results expressed as mean \pm SD. $p<0.05$.

IL-6 increased in TKD group in immediate and 24h post exercise experiments but it decreased at $24 \mathrm{hr}$ compared with immediate post exercise ones (from 0.69 at baseline to 0.91 at immediate post and to 0.89 at 24 after exercise) $(p<0.05)$ (figure 6$)$.

Serum C-reactive protein remained unchanged in immediate post exercise experiment and it increased at $24 \mathrm{~h}$ after exercise ones in both groups (untrained: from $0.43 \pm 0.04$ at baseline to $0.46 \pm 0.02$ and $1.01 \pm 0.03$ at immediate and $24 \mathrm{~h}$ after exercise respectively; TKD: from $0.42 \pm 0.03$ at baseline to $0.44 \pm \ldots$ and $0.77 \pm 0.01$ at immediate and $24 \mathrm{~h}$ after training respectively) $(p<0.05)$ (figure 7$)$.

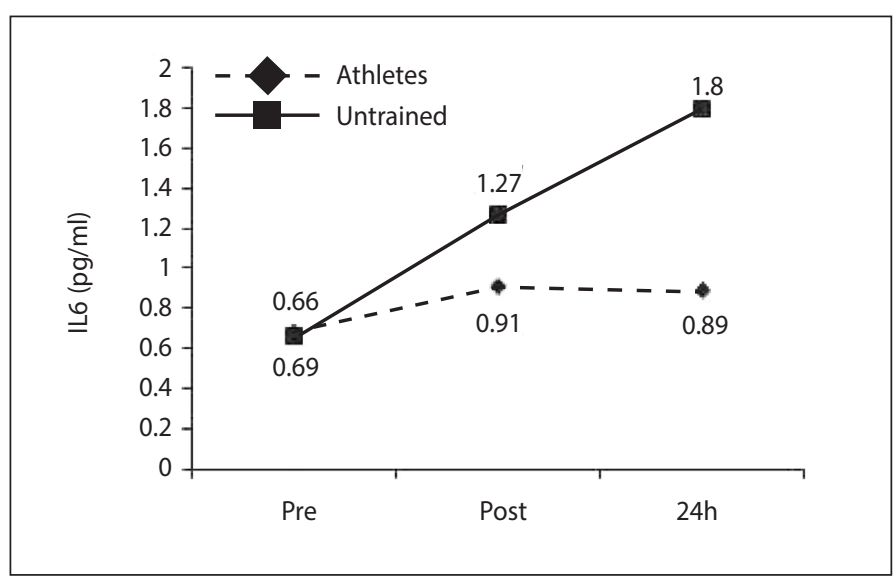

Figure 6. Baseline, changes in serum IL-6 immediate and 24h after exercise. Results expressed as mean \pm SD. $p<0.05$.

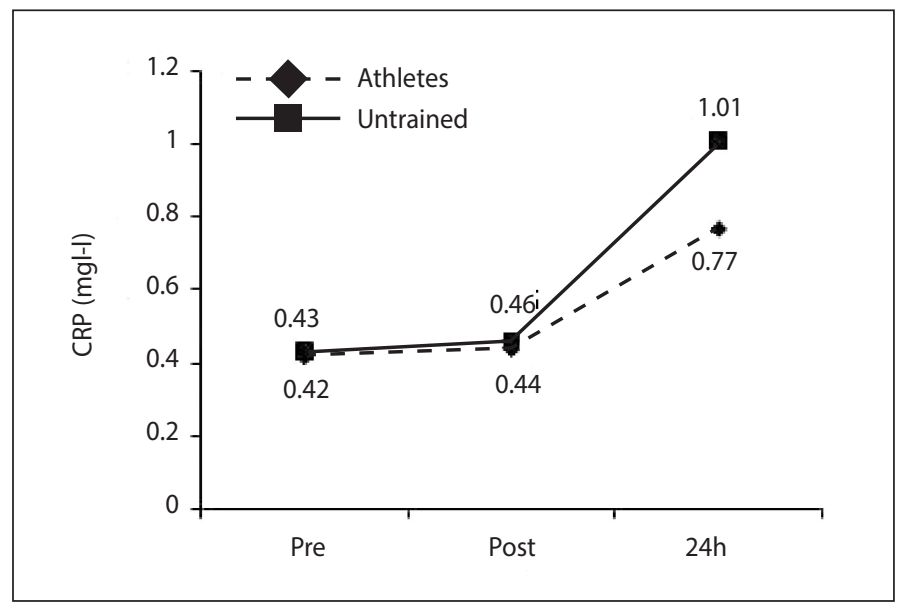

Figure 7. Baseline, changes in serum CRP immediate and 24h after exercise. Results expressed as mean \pm SD. $p<0.05$.

\section{DISCUSSION}

The objective of this study was to conduct a survey for measuring alterations in specific inflammatory and biochemical markers by carrying out experiments in pre, immediate and 24 after an elastic exercise sessions in taekwondo athletes and untrained men. According to the results of the present study, an acute bout of progressive elastic-band exercise induced time dependent changes in various inflammatory markers indicative of muscle damage.

The marked enhancements of DOMS, CK, LDH, LL-6 and CRP, have provided indirect evidence of muscle microtrauma after acute bout of an acute bout of progressive elastic-band. I Surveys about the effect of elastic-band on muscle damages have been rare now. In previous studies, muscle damage following intensive resistant exercise same elastic- band mode has been attributed to the mechanical stress on the contractile apparatus during eccentric contraction ${ }^{14}$. In other hand other mechanism are that elastic-band exercise may induce muscle damage because of the forces produced during ground impact and associated eccentric contraction ${ }^{5}$. Also a potential explanation for this result has been offered by Cronin et al..$^{15}$. They reported an increase in electromyographic activity of the quadriceps muscle in the late eccentric phase of motion during ER exercise. They have speculated that increasing segment velocity at the beginning of the eccentric phase, due to the recoil of force from the elastic device, would increase segment momentum which requires a greater muscle force to decelerate the load at the end of the eccentric phase. Linked with this speculative explanation is scientific evidence that demonstrates exacerbation of muscle damage when a given load is 
administered to the muscle at the end of eccentric phase ${ }^{16}$

The concentration of serum CK demonstrated an increasing trend $24 \mathrm{hrs}$ after termination of each mode of exercise training. Considering that our subjects were relatively untrained we anticipated a marked increase in serum CK following both the ER training sessions. However the magnitude of the serum CK response (87-135 IU/liter) was relatively very low compared with reports of 20,000 IU/liter following high-force eccentric contractile work ${ }^{17,18}$. The low serum CK, which it have been approved by previous investigation ${ }^{5}$, response of the present study may reflect a limited eccentric contraction component of the ER exercise bouts.

The present DOMS rise ( 3-5) may be considered moderate compared with the respective values after eccentric and other exercise protocols ${ }^{19}$ in a 10-point scale that may be interfered as limited muscle damage. This result is in parallel with other study on ER exercises ${ }^{5}$. But immediately increase DOMS after training in untrained men compared with athletes may be shown that DOMS in athletes, because of having previous eccentric training and compatibility due to effect of repeated bout, was lower compared with untrained men that it can be shown muscle recovery is faster in athletes.

$\mathrm{LDH}$ protein emission from muscle may be attributed to the increased permeability of serum membrane or intramuscular vasculature ${ }^{20}$. During eccentric phase activation produces higher tension per cross-sectional area of active muscle mass compared with concentric actions resulting in significant structural muscle damage ${ }^{21}$

Leukocyte following acute bout of elastic-band exercise elicits an acute phase inflammatory response characterized by leukocyte infiltration in the damaged area. Leukocytes exhibit a transient rise immediately post exercise followed by decreased at 24 hours later. This data is similar with previous study that had been done on plyometric training ${ }^{12,22}$.

$\mathrm{IL}-6$ is primary cytokines in the control of immune reaction during the acute-phase inflammatory response and the subsequent repair process. IL-6 is implicated in hepatocyte-derived proteins production, cortisol production, and neutrophil degranulation ${ }^{23}$. In our study, IL-6 increased only immediate after exercise and at a lesser extent compared other study on eccentric exercise ${ }^{12}$, which is probably related

\section{REFERENCES}

1. Topal V RN, Yilmaz S, Camliguney AF, Kaya F. The effect of resistance training with elastic bands on strike force at Taekwondo. Am Int J Contemp Res. 2011;1:140-4.

2. Stevenson MW, Warpeha JM, Dietz CC, Giveans RM, Erdman AG. Acute effects of elastic bands during the free-weight barbell back squat exercise on velocity, power, and force production. J Strength Cond Res. 2010;24(11):2944-54

3. Wallace BJ, Winchester JB, McGuigan MR. Effects of elastic bands on force and power characteristics during the back squat exercise. J Strength Cond Res. 2006;20(2):268-72

4. Israetel MA, McBride JM, Nuzzo JL, Skinner JW, Dayne AM. Kinetic and kinematic differences between squats performed with and without elastic bands. J Strength Cond Res. 2010;24(1):190-4

5. Aboodarda SJ, George J, Mokhtar AH, Thompson M. Muscle strength and damage following two modes of variable resistance training. J Sports Sci Med. 2011;10(4):635-42.

6. Proske U, Morgan DL. Muscle damage from eccentric exercise: mechanism, mechanical signs, adaptation and clinical applications. J Physiol. 2001;537(Pt 2):333-45.

7. Jones DA, Newham DJ, Round JM, Tolfree SE. Experimental human muscle damage: morphological changes in relation to other indices of damage. J Physiol. 1986;375:435-48.

8. Peake J, Nosaka K, Suzuki K. Characterization of inflammatory responses to eccentric exercise in humans. Exerc Immunol Rev. 2005;11:64-85.

9. Philippou A, Bogdanis G, Maridaki M, Halapas A, Sourla A, Koutsilieris M. Systemic cytokine response following exercise-induced muscle damage in humans. Clin Chem Lab Med. 2009;47(6):777-82.

10. Mourkioti F, Rosenthal N. IGF-1, inflammation and stem cells: interactions during muscle regeneration. Trends Immunol. 2005;26(10):535-42.

11. Dinarello CA. Proinflammatory and anti-inflammatory cytokines as mediators in the pathogenesis of septic shock. Chest. 1997;112(6 Suppl):321S-329S.

12. Chatzinikolaou A, Fatouros IG, Gourgoulis V, Avloniti A, Jamurtas AZ, Nikolaidis MG, et al. Time course of changes in performance and inflammatory responses after acute plyometric exercise. J Strength Cond Res. 2010;24(5):1389-98.

13. Saxton JM, Claxton D, Winter E, Pockley AG. Peripheral blood leucocyte functional responses to acute eccentric exercise in humans are influenced by systemic stress, but not by exercise-induced muscle damage. Clin Sci (Lond). 2003;104(1):69-77.

14. Moritani T, Muramatsu S, Muro M. Activity of motor units during concentric and eccentric contractions. Am J Phys Med. 1987;66(6):338-50 to the smaller of muscle damage induced by elastic-band exercise as compared with other exercise models. This was indicated by the increase in serum IL-6 concentrations within hour's post-exercise, corroborating previously published data ${ }^{7,9,24}$. The early increase in serum IL-6 post eccentric exercise-induced muscle damage has been assumed to originate from inflammatory cells infiltrating damaged skeletal muscle ${ }^{9}$.

CRP, an acute phase protein, synthesized and released by the liver after stimulation by IL-6 and cortiso ${ }^{23}$. CRP protein elevation has been related with monocyte activation and adhesion molecules synthesis that recruit leukocytes ${ }^{25}$. In present study, IL-6 preceded CRP peak in the circulation and CRP peak was done at 24 hours after training. It appears that, CRP increase within 24 hours of recovery as previously reported for other exercise models ${ }^{12,19}$. In contrast other research on plyometric exercise suggested that CRP increased only 2 days after training ${ }^{22}$. In other hands CRP production in our investigation is lower than plyometric and severe exercise ${ }^{12,26}$ that it is same with the study on resistance or aerobic exercise ${ }^{27}$.

\section{CONCLUSION}

In general, the current study suggests a concurrence between peak serum CK activity, peak rating of muscle soreness, CRP and IL-6 production which was significantly higher than the pretest measurement in both groups and elastic-band exercise could cause muscle damage. Also elevation in biochemical markers in untrained group was more than athletes group. In other hand, present investigation shows that an acute bout of resistance exercise (elastic-band) induces muscle damage and DOMS a smaller magnitude in comparison with other exercise forms. However, the results of the present study point to the need for further research on the effectiveness of the elastic-band exercise in developing muscle strength and hypertrophy with an extended training programme.

All authors have declared there is not any potential conflict of interests concerning this article.

15. Cronin J, McNair PJ, Marshall RN. The effects of bungy weight training on muscle function and functional performance. J Sports Sci. 2003;21(1):59-71.

16. Lieber RL, Thornell LE, Fridén J. Muscle cytoskeletal disruption occurs within the first 15 min of cyclic eccentric contraction. J Appl Physiol (1985). 1996;80(1):278-84

17. Byrnes WC, Clarkson PM, White JS, Hsieh SS, Frykman PN, Maughan RJ. Delayed onset muscle soreness following repeated bouts of downhill running. J Appl Physiol (1985). 1985;59(3):710-5.

18. Schwane JA, Johnson SR, Vandenakker CB, Armstrong RB. Delayed-onset muscular soreness and plasma CPK and LDH activities after downhill running. Med Sci Sports Exerc. 1983;15(1):51-6.

19. Ispirlidis I, Fatouros IG, Jamurtas AZ, Nikolaidis MG, Michailidis I, Douroudos I, et al. Time-course of changes in inflammatory and performance responses following a soccer game. Clin J Sport Med. 2008;18(5):423-31.

20. Cannon JG, Orencole SF, Fielding RA, Meydani M, Meydani SN, Fiatarone MA, et al. Acute phase response in exercise: interaction of age and vitamin $\mathrm{E}$ on neutrophils and muscle enzyme release. Am J Physiol. 1990;259(6 Pt 2):R1214-9.

21. Clarkson PM, Tremblay I. Exercise-induced muscle damage, repair, and adaptation in humans. J App Physiol (1985). 1988;65(1):1-6.

22. Dousset E, Avela J, Ishikawa M, Kallio J, Kuitunen S, Kyröláinen H, et al. Bimodal recovery pattern in human skeletal muscle induced by exhaustive stretch-shortening cycle exercise. Med Sci Sports Exerc. 2007:39(3):453-60.

23. Steensberg A, Fischer CP, Keller C, Møller K, Pedersen BK. IL-6 enhances plasma IL-1 ra, IL-10, and cortisol in humans. Am J Physiol Endocrinol Metab. 2003;285(2):E433-7.

24. Toft $A D$, Jensen $L B$, Bruunsgaard $H$, Ibfelt T, Halkjaer-Kristensen J, Febbraio $M$, et al. Cytokine response to eccentric exercise in young and elderly humans. Am J Physiol Cell Physiol. 2002;283(1):C289-95.

25. Torzewski M, Rist C, Mortensen RF, Zwaka TP, Bienek M, Waltenberger J, et al. C-reactive protein in the arterial intima: role of C-reactive protein receptor-dependent monocyte recruitment in atherogenesis. Arterioscler Thromb Vasc Biol. 2000;20(9):2094-9.

26. Pournot H, Bieuzen F, Louis J, Mounier R, Fillard JR, Barbiche E, et al. Time-course of changes in inflammatory response after whole-body cryotherapy multi exposures following severe exercise. PLoS One. 2011;6(7):e22748.

27. Donges $C E$, Duffield R, Drinkwater EJ. Effects of resistance or aerobic exercise training on interleukin-6, C-reactive protein, and body composition. Med Sci Sports Exerc. 2010;42(2):304-13

\section{ERRATA}

No artigo intitulado 'EFFECT OF ELASTIC - BAND EXERCISE ON MUSCLE DAMAGE AND INFLAMMATORY RESPONSES IN TAEKWONDO ATHLETES" de autoria de KEIVAN GADRUNI, HEMN MAHM-

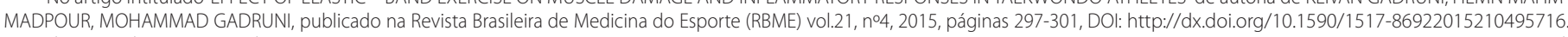

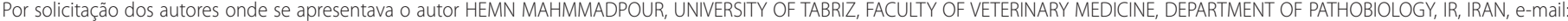

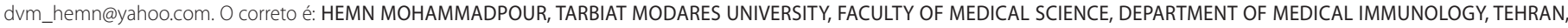
IRAN. e-mail: h.mohammadpour@modares.ac.ir 